\title{
In-situ STEM study on the morphological evolution of copper-based nanoparticles during high-temperature redox reactions
}

Sharmin Sharna ${ }^{a, b}$, Mounib Bahri ${ }^{b}$, Corinne Bouillet ${ }^{b}$, Virgile Rouchon ${ }^{a}$, Arnold Lambert ${ }^{a}$, Anne-

Sophie Gay a, David Chiche a and Ovidiu Ersen ${ }^{*}$ b

a. IFP Energies Nouvelles, Rond-Point de l'échangeur de Solaize, 69360 Solaize, France

b. Institute de Physique et Chimie des Matériaux de Strasbourg (IPCMS), UMR 7504 S - ni er ité de Strasbourg, 23 rue du Loess, BP 43, Strasbourg Cedex 2, France

*Email: ovidiu.ersen@ipcms.unistra.fr

\section{Electronic Supporting Information}

\section{Nanoparticle synthesis}

\subsection{Sputtered nanoparticles:}

Three sputtering experiments were conducted varying the initial NP formation steps (presented in Table S1). The thickness of the film in the $1^{\text {st }}$ experiment was $2 \mathrm{~nm}$ while in the $2^{\text {nd }}$ and $3^{\text {rd }}$ experiment $1 \mathrm{~nm}$ films were used. For all three experiments, the samples were heated from room temperature to $150{ }^{\circ} \mathrm{C}$ at $5{ }^{\circ} \mathrm{C} / \mathrm{min}$ and kept for 2 hours. However, no particles were formed at this temperature, and the system had to be heated to $300{ }^{\circ} \mathrm{C}$. For experiments 1 and 2, a slower heating rate of $5{ }^{\circ} \mathrm{C} / \mathrm{min}$ was used in contrast to $5^{\circ} \mathrm{C} / \mathrm{sec}$ for the $3^{\text {rd }}$ experiment.

Table S1: Experimental parameters used for the formation of sputtered nanoparticles.

\begin{tabular}{|c|c|c|c|c|c|c|}
\hline Samples & $\begin{array}{l}\text { Film } \\
\text { thickness }\end{array}$ & $\begin{array}{l}\text { Gas } \\
\text { atmosphere }\end{array}$ & Heating rate & $\begin{array}{l}\text { Final } \\
\text { Temperature }\end{array}$ & Duration & $\begin{array}{l}\text { NP average size } \\
\text { and density }\end{array}$ \\
\hline Sputt-1 & $2 \mathrm{~nm}$ & $0.5 \mathrm{bar} \mathrm{H}_{2}$ & $5{ }^{\circ} \mathrm{C} / \mathrm{min}$ & $30{ }^{\circ} \mathrm{C}$ & 2 hours & $\begin{array}{c}4 \pm 2(<10 \mathrm{~nm}) \\
35 \pm 7(>10 \mathrm{~nm}) \\
675 \mathrm{NP} / \mu \mathrm{m}^{2}\end{array}$ \\
\hline Sputt-2 & $1 \mathrm{~nm}$ & $0.5 \mathrm{bar} \mathrm{H}_{2}$ & $5{ }^{\circ} \mathrm{C} / \mathrm{min}$ & $300^{\circ} \mathrm{C}$ & 2 hours & $\begin{array}{c}4 \pm 1(<10 \mathrm{~nm}) \\
21 \pm 6(>10 \mathrm{~nm}) \\
1015 \mathrm{NP} / \mu \mathrm{m}^{2}\end{array}$ \\
\hline Sputt-3 & $1 \mathrm{~nm}$ & $0.5 \mathrm{bar} \mathrm{H}_{2}$ & $5{ }^{\circ} \mathrm{C} / \mathrm{s}$ & $300^{\circ} \mathrm{C}$ & 2 hours & $\begin{array}{r}9 \pm 4 \mathrm{~nm} \\
3730 \mathrm{NP} / \mu \mathrm{m}^{2}\end{array}$ \\
\hline
\end{tabular}




\section{a) Sputt-1}

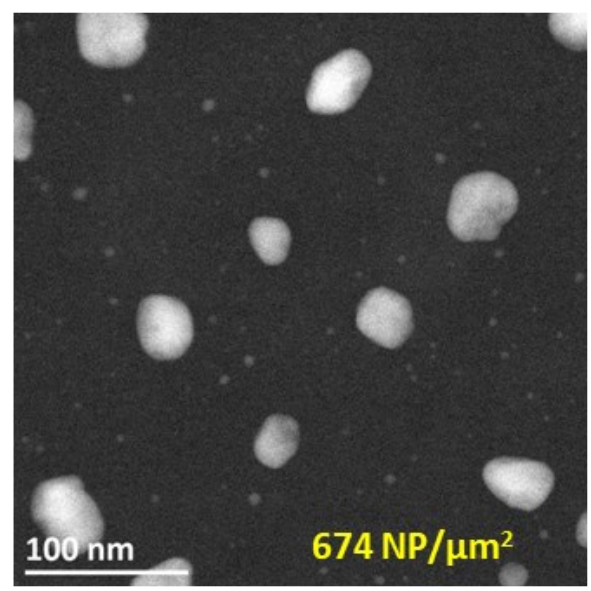

c) Sputt-2

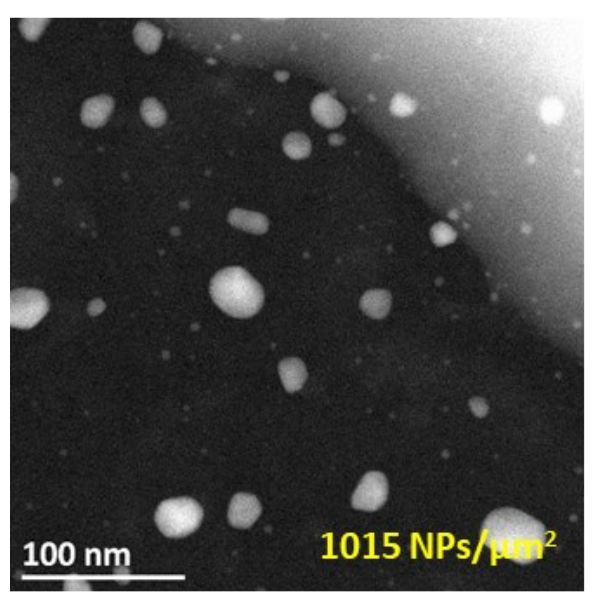

e) Sputt-3

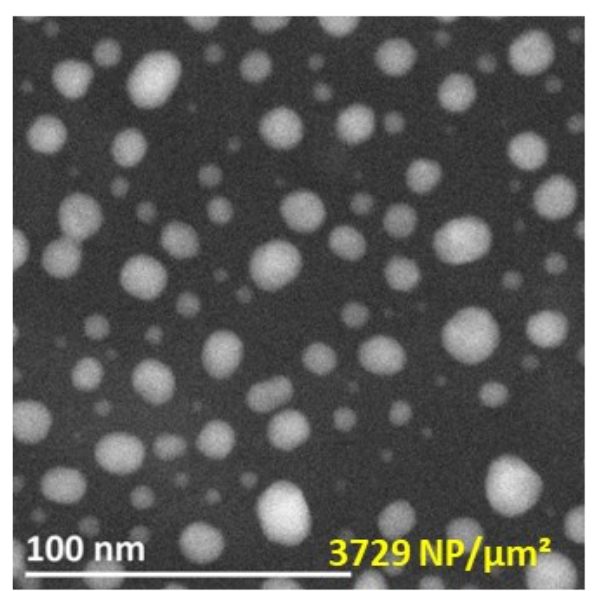

b) PSD, Sputt-1

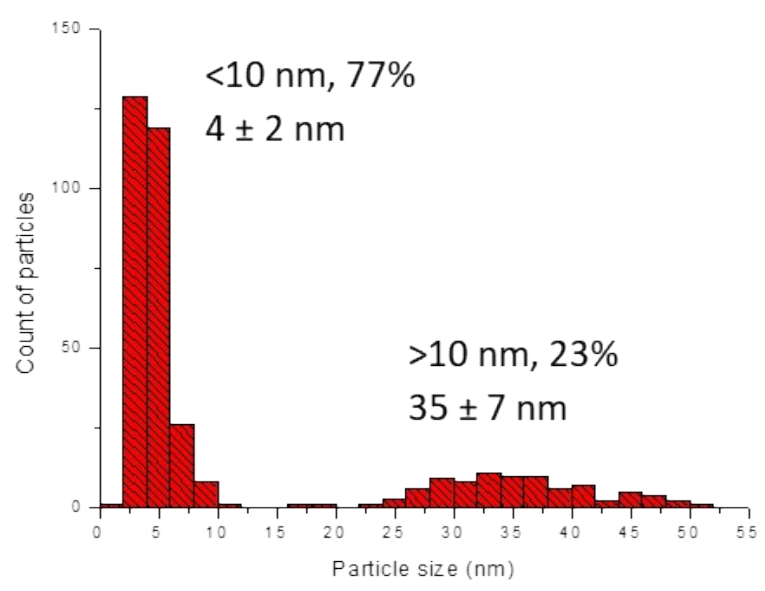

d) PSD, Sputt-2

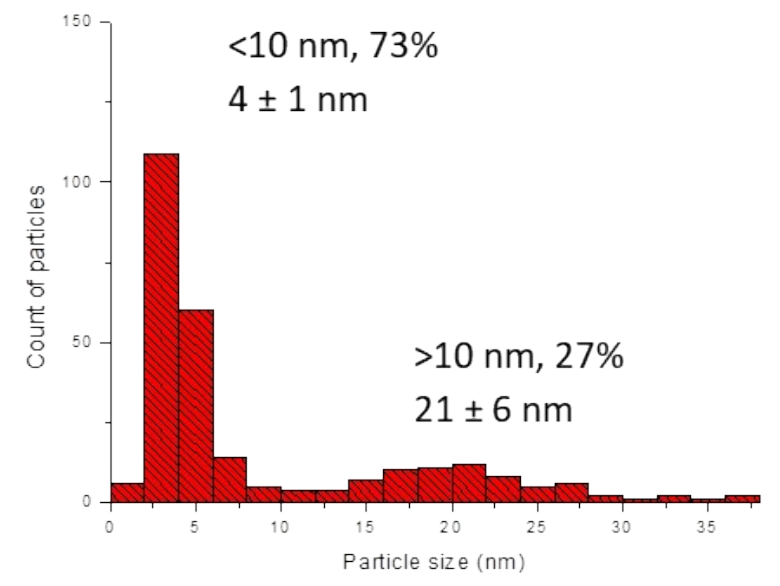

f) PSD, Sputt-3

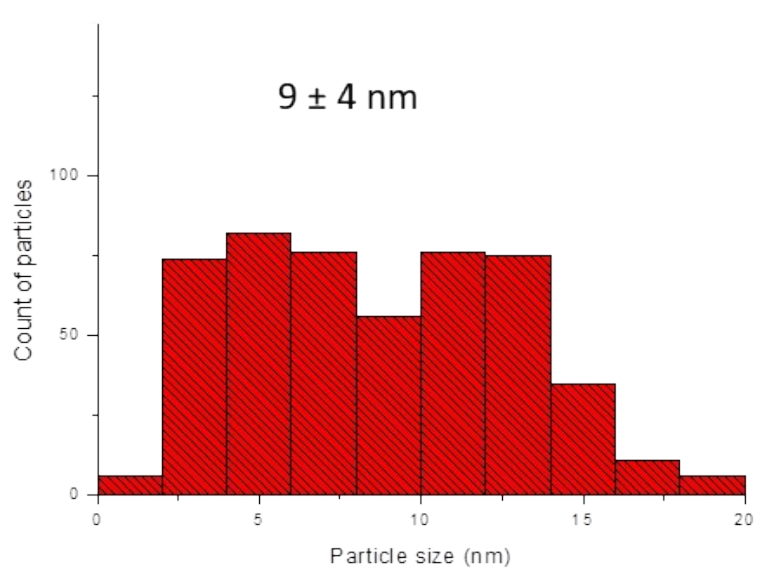

Figure S1: (a-c) Formation of Cu nanoparticles at different experimental conditions. (a) Sputt-1 (c) Sputt-2 (d) Sputt- 3 and their corresponding particle size distribution in (d, e and f). 


\subsection{Chemically synthesized nanoparticles:}

a) $200^{\circ} \mathrm{C}, \mathrm{Ar}$

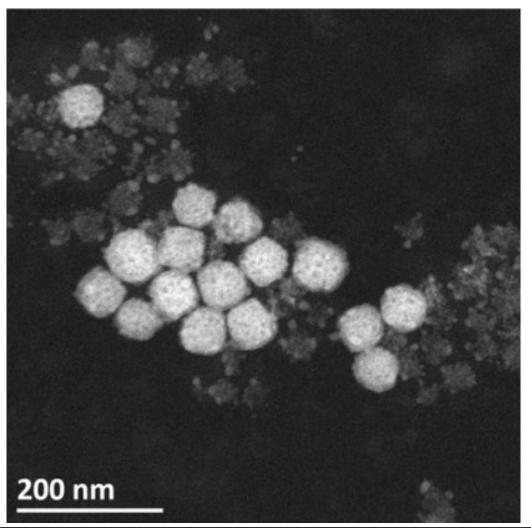

b) $200{ }^{\circ} \mathrm{C}, \mathrm{H}_{2}$

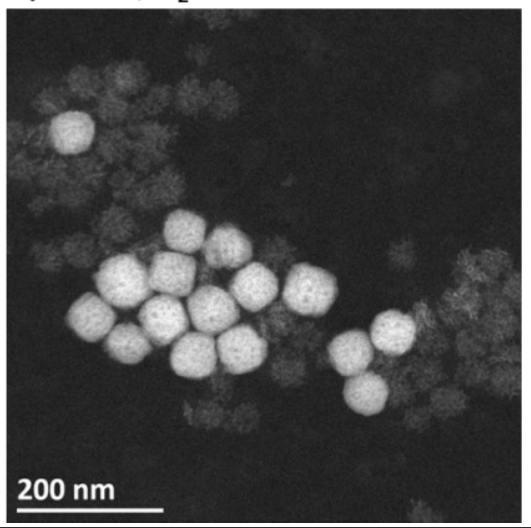

c) $500^{\circ} \mathrm{C}, \mathrm{H}_{2}, 45 \mathrm{~min}$

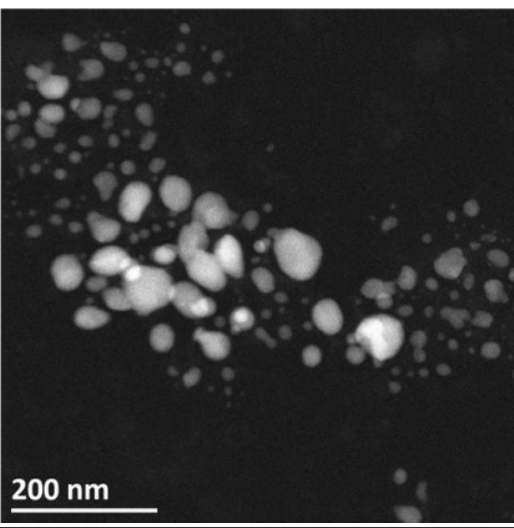

Figure S2: Heat treatment of sample: Syn-1: a) at $200^{\circ} \mathrm{C}$ under Argon, b) at $200{ }^{\circ} \mathrm{C}$ under $\mathrm{H}_{2}$ and c) at $500{ }^{\circ} \mathrm{C}$ after 42 min of gas flow.

Initially, the surface of the nanoparticles were passiviated by organic ligands and large particles were rather composed of smaller nanoparticles, aggregated together. Upon heating at $500{ }^{\circ} \mathrm{C}$, under $\mathrm{H}_{2}$ for an hour the organic layer is removed and the initial porous structure is lost, forming compact nanoparticles of metallic copper.

a) $500^{\circ} \mathrm{C}, \mathrm{H}_{2}, 45 \mathrm{~min}$

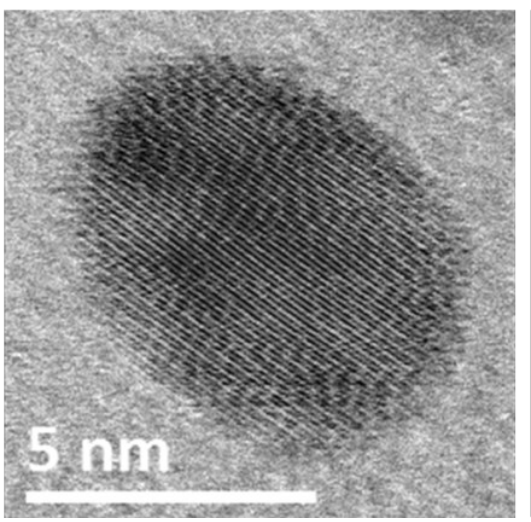

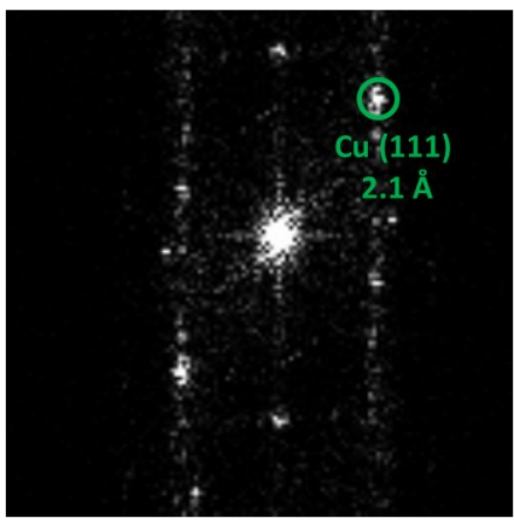

Figure S3: a) high resolution image (HR) of metallic copper after 45 min of heat treatment under $\mathrm{H}_{2}$ at $500{ }^{\circ} \mathrm{C}$ and Fast Fourier Transform (FFT) of the HR image. 


\section{In-situ STEM analysis}

\subsection{Oxidation of metallic Copper}

\subsubsection{Phases present}

a) $\mathrm{O}_{2}-300^{\circ} \mathrm{C}, 30 \mathrm{~min}$
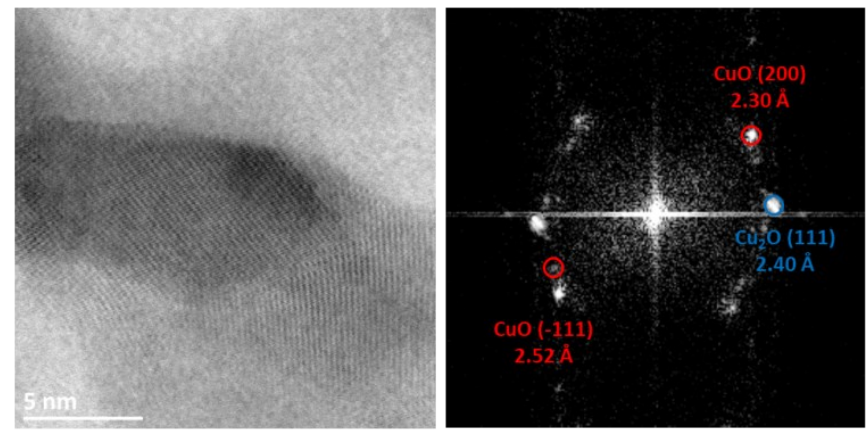

b) $\mathrm{O}_{2}-300^{\circ} \mathrm{C}, 1$ hour

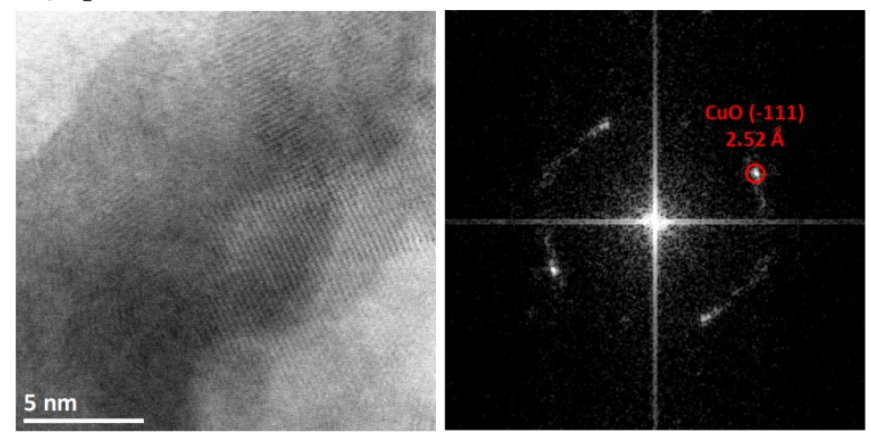

Figure S4: HR-STEM images of copper oxide during oxidation at $300{ }^{\circ} \mathrm{C}$, a) after $30 \mathrm{~min}$ of oxygen flow and b) after 1 hour of gas flow (inset contains Fast Fourier Transformation (FFT) pattern of the HRSTEM image). 


\subsubsection{Kirkendall Void Formation}

$4 \mathrm{Cu}(\mathrm{s})+\mathrm{O}_{2}(\mathrm{~g}) \rightarrow 2 \mathrm{Cu}_{2} \mathrm{O}(\mathrm{s})$

Calculations - ${ }^{\Delta g_{C u_{2} \mathrm{O}}}$

$\Delta g_{\mathrm{Cu}_{2} \mathrm{O}}=-339758+149.14 \mathrm{~T} \quad 1$

\section{Diffusion Coefficient $\left(\mathrm{cm}^{2} / \mathrm{s}\right)$ :}

Using the reaction-diffusion model developed by Svoboda et al. the self-diffusion coefficients of $\mathrm{Cu}$ in $\mathrm{Cu}_{2} \mathrm{O}$ is calculated to eventually determine the activation energy of diffusion and pre-exponential parameter to fit Arrhenius model for a temperature range of $323-773 \mathrm{~K}^{2}$.

$t=\frac{\operatorname{ARTR}_{0}^{2}}{D_{\text {Cu in } \mathrm{Cu}_{2} \mathrm{O}}\left|\Delta g_{\mathrm{Cu}_{2} \mathrm{O}}\right|}$

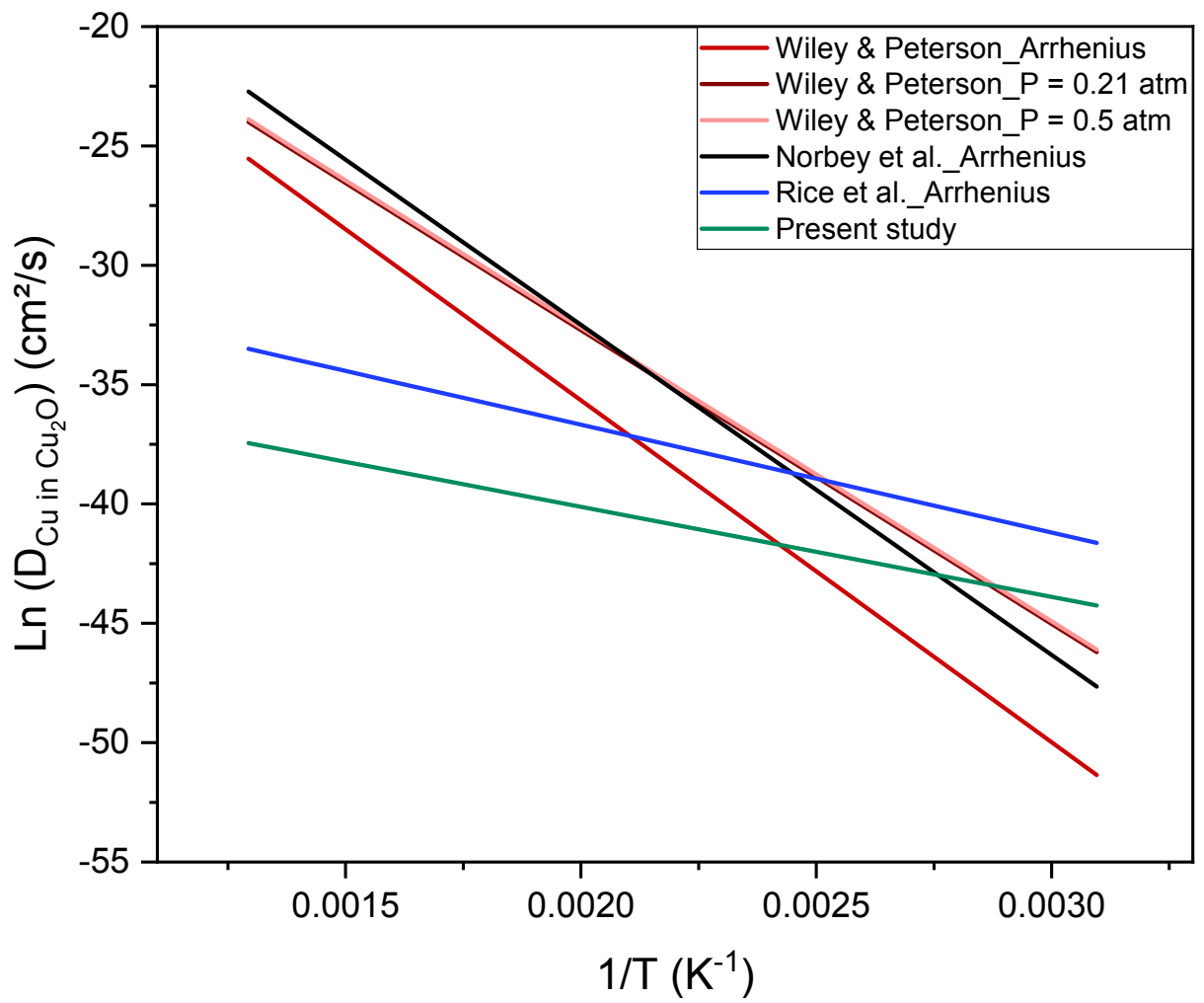

Figure S5: Comparison of self -diffusion coefficient of copper in $\mathrm{Cu}_{2} \mathrm{O}$ in bulk sample by Wiley and Peterson ${ }^{3}$ and Norby et al. ${ }^{4}$ and in nanoparticles by Rice et al. ${ }^{5}$ and the current study. 


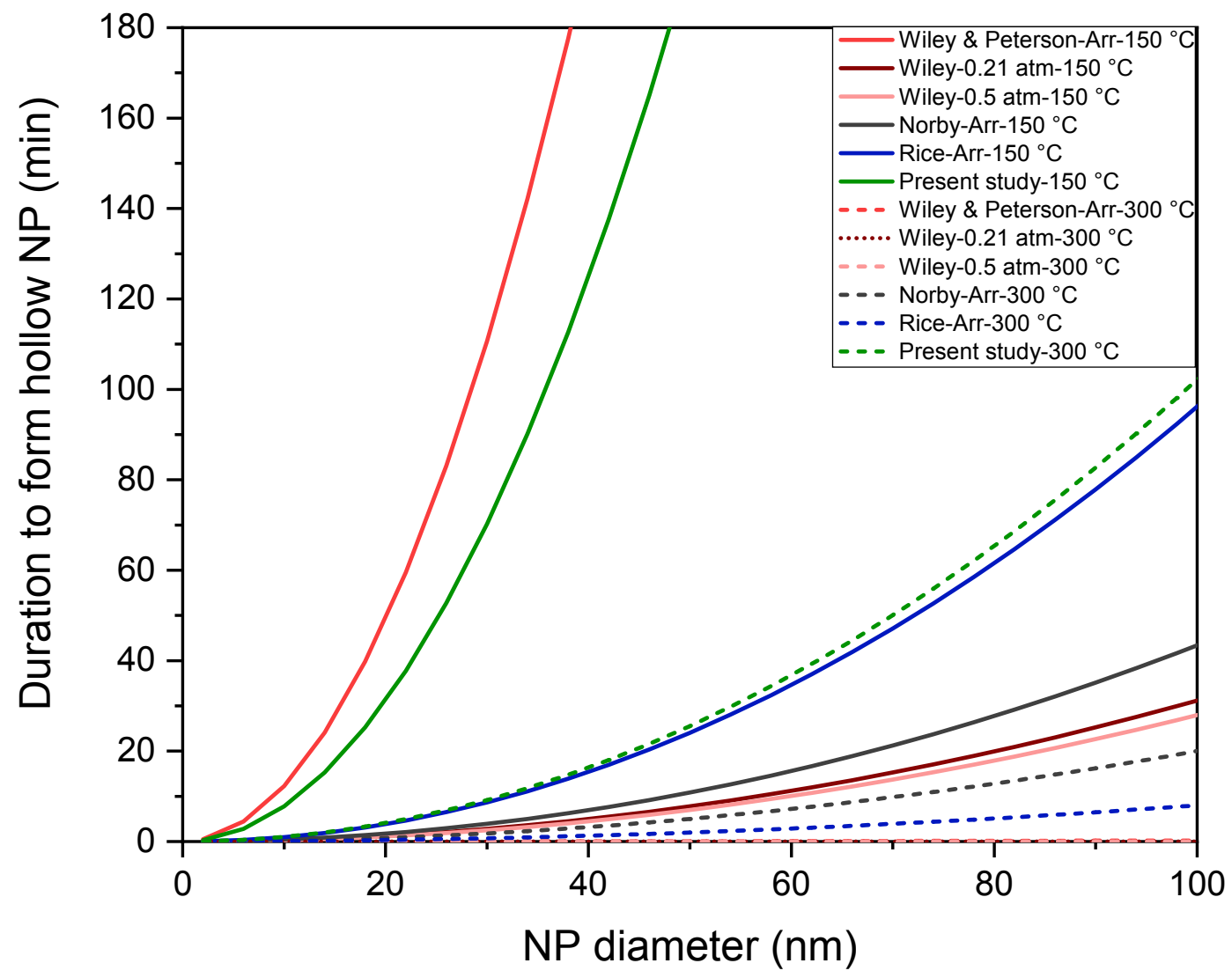

Figure S6: The duration of completion to form Kirkendall void as a function of nanoparticle diameter using the diffusion coefficients at a temperature of $150^{\circ} \mathrm{C}$ and $300^{\circ} \mathrm{C}$. 


\subsection{Nanoparticle Size Distribution:}

a) $0_{2}-300{ }^{\circ} \mathrm{C}, 30 \mathrm{~min}$

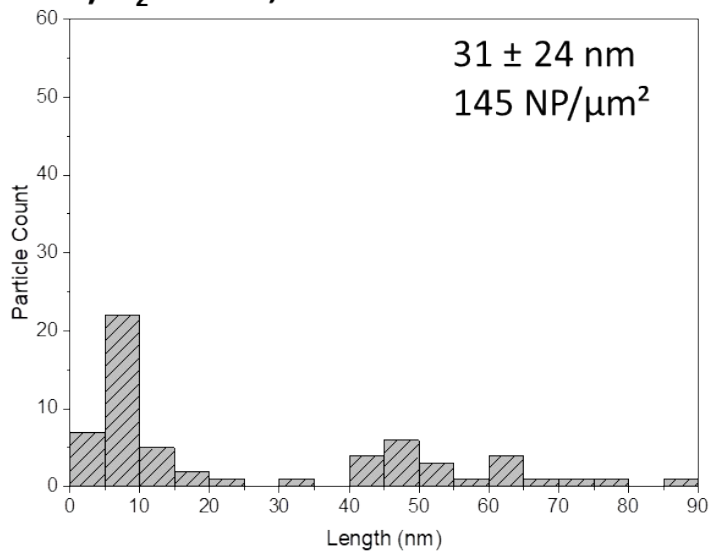

b) $\mathrm{H}_{2}-300{ }^{\circ} \mathrm{C}, 10 \mathrm{~min}$

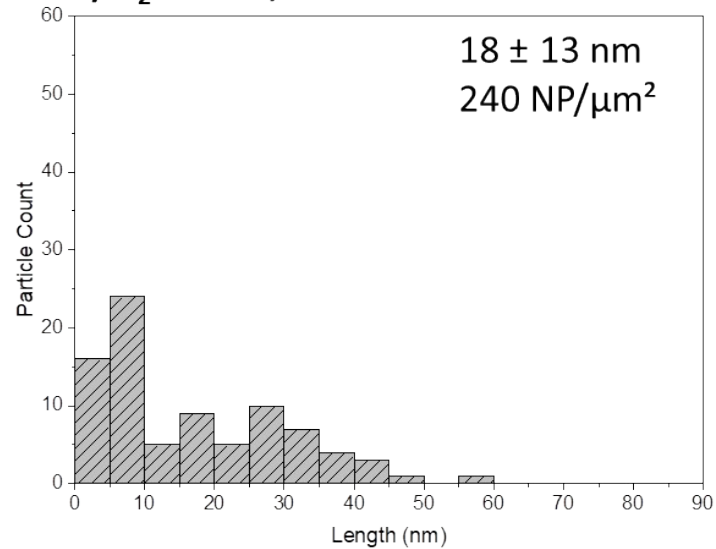

Figure S7: PSD for the NPs at $300{ }^{\circ} \mathrm{C}$ under a) $\mathrm{O}_{2}$ after $30 \mathrm{~min}$ of oxidation and b) $\mathrm{H}_{2}$ after $10 \mathrm{~min}$. Sample: Sputt-1.

a) $\mathrm{O}_{2}-400{ }^{\circ} \mathrm{C}, 45 \mathrm{~min}$

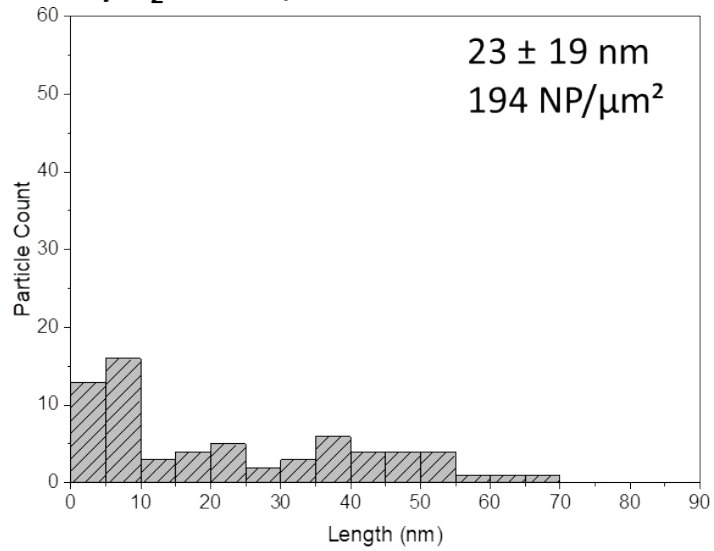

b) $\mathrm{H}_{2}-400{ }^{\circ} \mathrm{C}, 20 \mathrm{~min}$

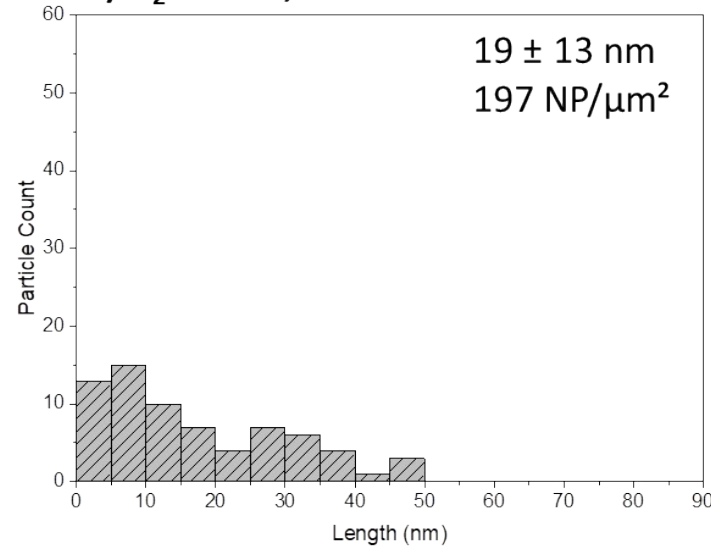

Figure S8: PSD of the nanoparticles at $400{ }^{\circ} \mathrm{C}$, a) copper oxide NPs under oxygen after $45 \mathrm{~min}$ and b) under hydrogen after $20 \mathrm{~min}$ of gas flow. Sample: Sputt-1. 
a) $\mathrm{O}_{2} 500^{\circ} \mathrm{C}$, after $30 \mathrm{~min}$

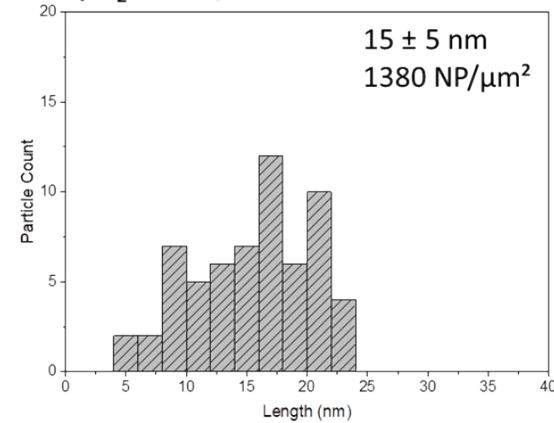

b) $\mathrm{H}_{2}-500{ }^{\circ} \mathrm{C}$, after $30 \mathrm{~min}$

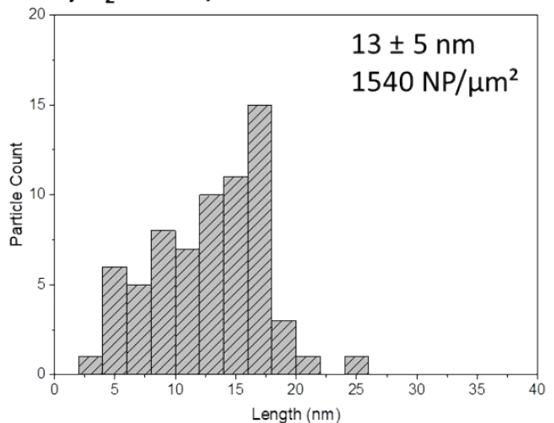

c) $\mathrm{O}_{2}-500{ }^{\circ} \mathrm{C}$, after $35 \mathrm{~min}$

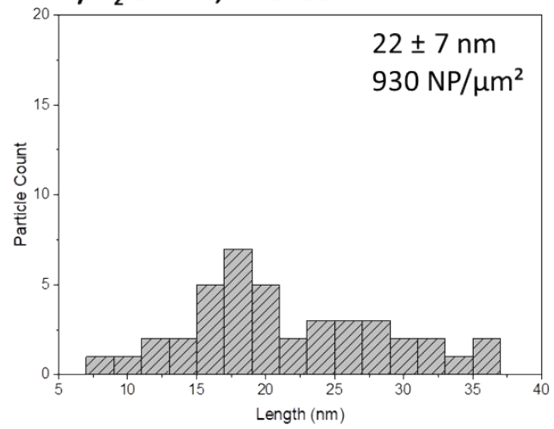

Figure S9: PSD of the NPs at $500^{\circ} \mathrm{C}:$ a) under $\mathrm{O}_{2}$ after 30 min of gas flow b) under $\mathrm{H}_{2}$ after 30 min of gas flow and c) NPs after re-oxidation after $35 \mathrm{~min}$ of oxidation. The images are not from the same area of observation. Sample: Sputt-3. 


\subsection{Reduction of Copper Oxide Nanoparticles}

\subsubsection{Reduction of hollow NPs at $250^{\circ} \mathrm{C}$}
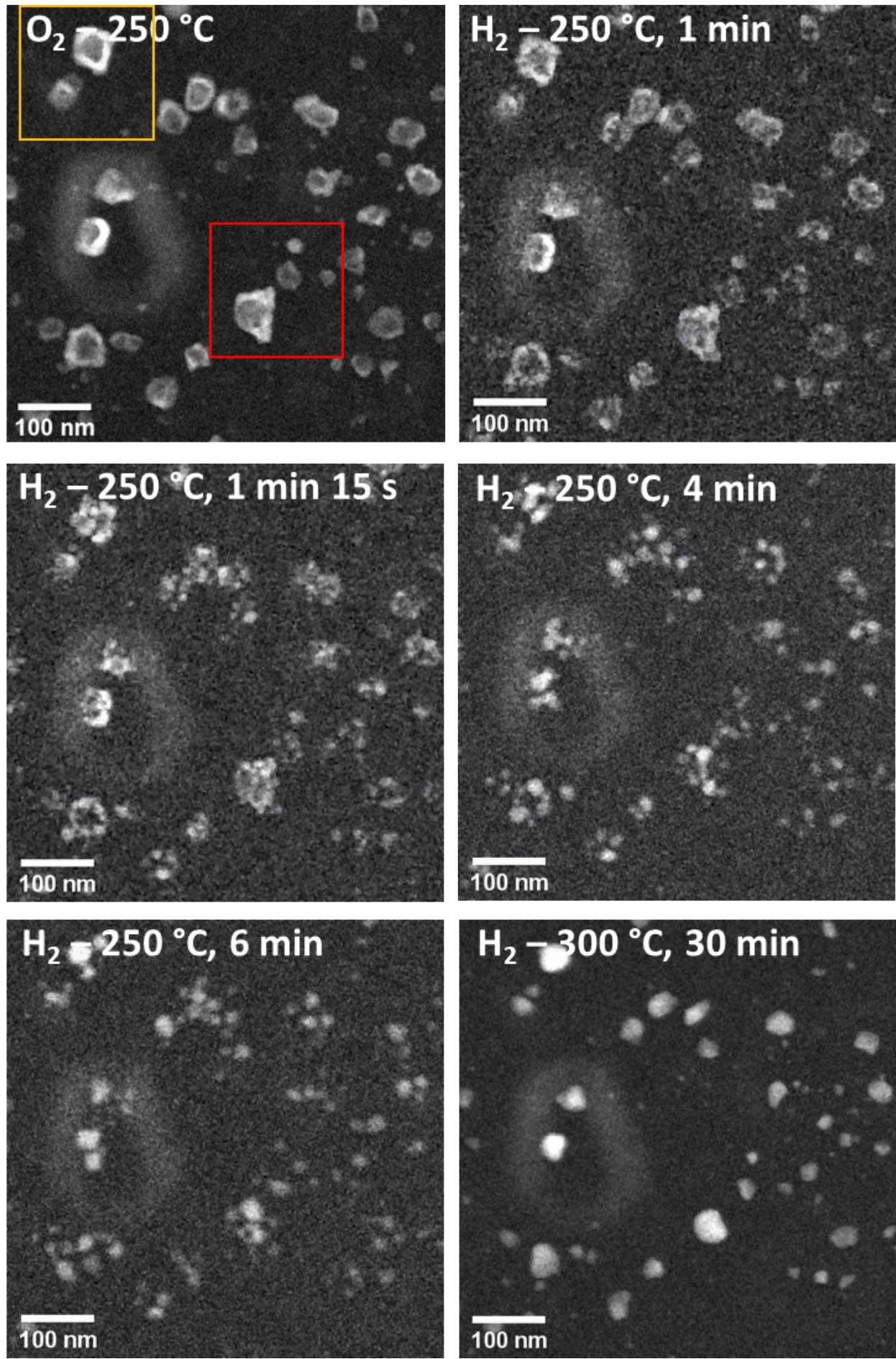

Figure S10: Reduction of hollow copper oxide nanoparticles under hydrogen at $250{ }^{\circ} \mathrm{C}$ up to 6 min and heated to $300{ }^{\circ} \mathrm{C}$, after $30 \mathrm{~min}$. Sample: Sputt-2. 

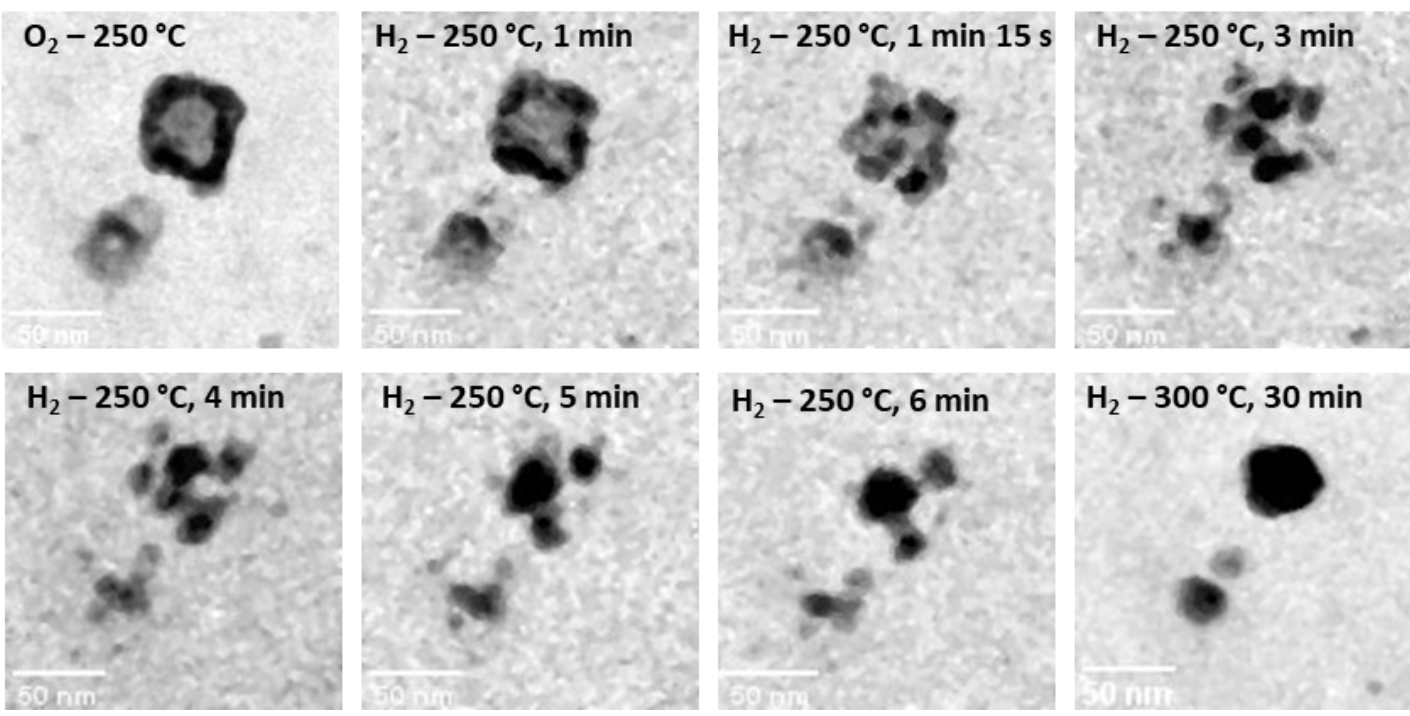

Figure S11: Reduction of hollow copper oxide nanoparticles under hydrogen at $250{ }^{\circ} \mathrm{C}$ up to 6 min and heated to $300^{\circ} \mathrm{C}$, after $30 \mathrm{~min}$. Area marked by yellow square on Figure S9. Sample: Sputt- 2 .
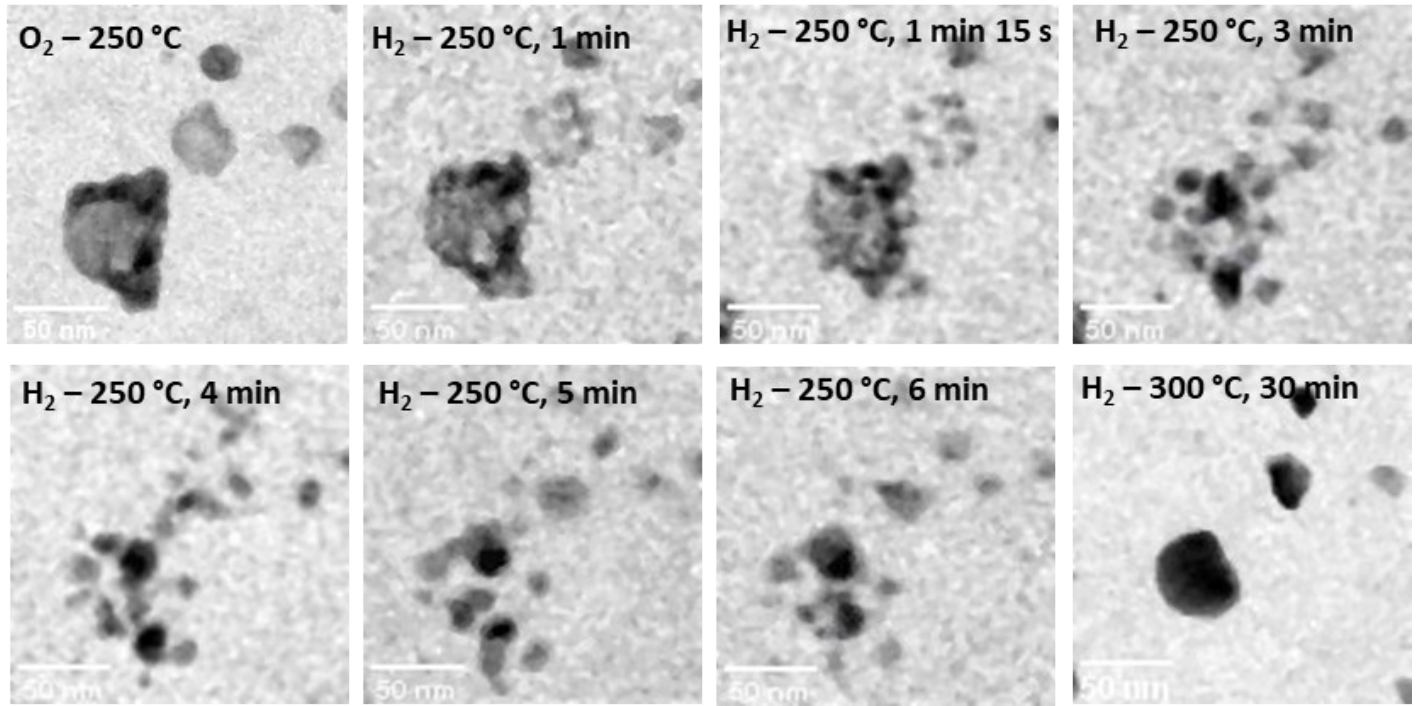

Figure S12: Reduction of hollow copper oxide nanoparticles under hydrogen at $250{ }^{\circ} \mathrm{C}$ up to 6 min and heated to $300^{\circ} \mathrm{C}$, after $30 \mathrm{~min}$. Area marked by red square on Figure S9. Sample: Sputt- 2 . 


\subsubsection{Reduction of hollow and compact NPs at $400^{\circ} \mathrm{C}$}
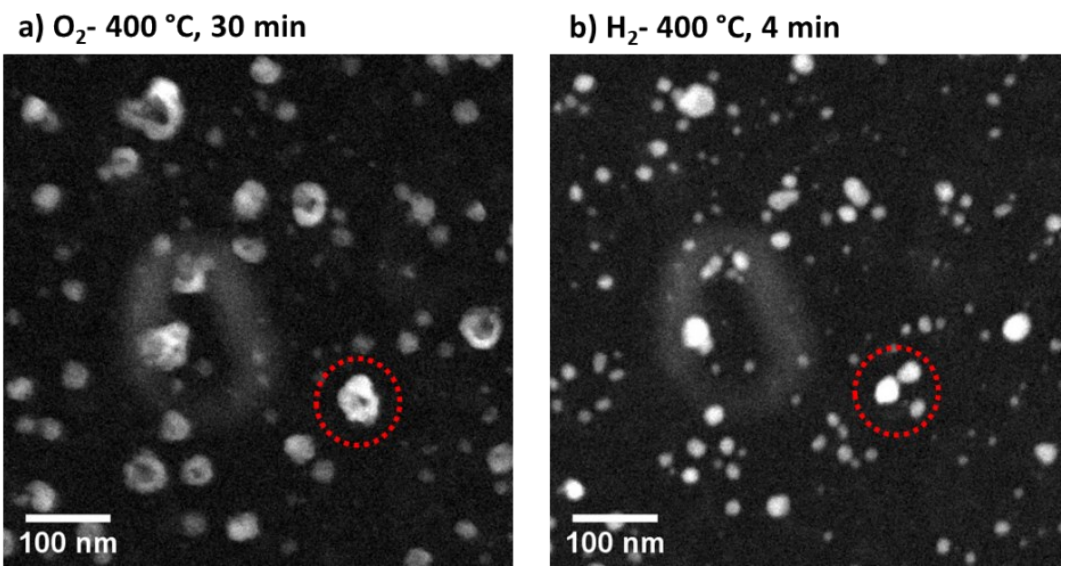

Figure S13: Reduction of Copper oxide nanoparticles at $400{ }^{\circ} \mathrm{C}$, a) copper oxide NPs under oxygen after 30 min and $b$ ) under hydrogen after 4 min of gas flow. Sample: Sputt - 2

a) $\mathrm{O}_{2}-400^{\circ} \mathrm{C}, 45 \mathrm{~min}$

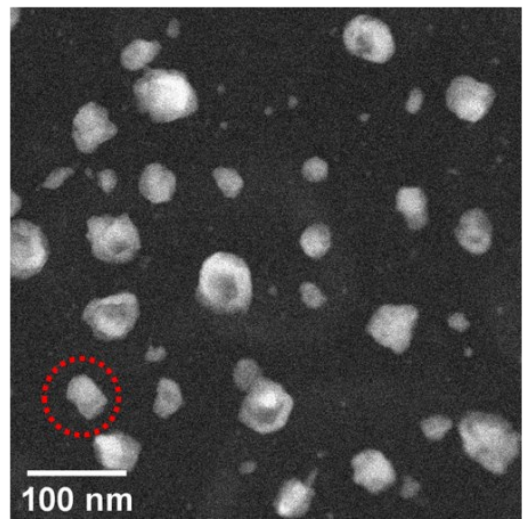

b) $\mathrm{H}_{2}-400^{\circ} \mathrm{C}, 20 \mathrm{~min}$

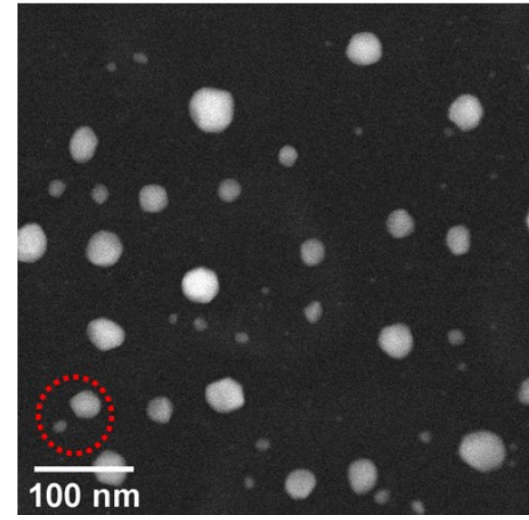

Figure S14: Reduction of Copper oxide nanoparticles at $400^{\circ} \mathrm{C}$, a) copper oxide NPs under oxygen after 45 min and b) under hydrogen after 20 min of gas flow. Sample: Sputt - 1 


\subsubsection{Reduction of compact NPs at $250^{\circ} \mathrm{C}$}

a) $\mathrm{O}_{2}-400^{\circ} \mathrm{C}, 20 \mathrm{~min}$

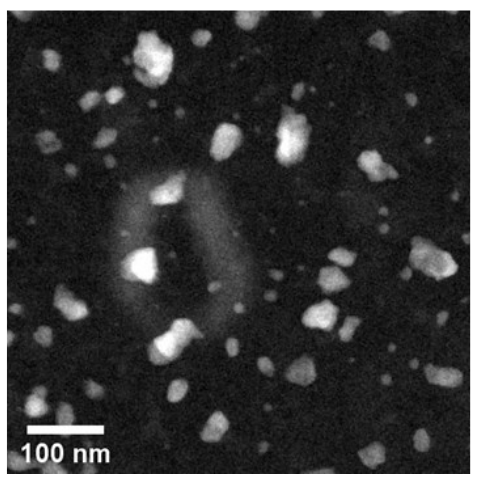

b) $\mathrm{H}_{2}-250^{\circ} \mathrm{C}, 4 \mathrm{~min}$

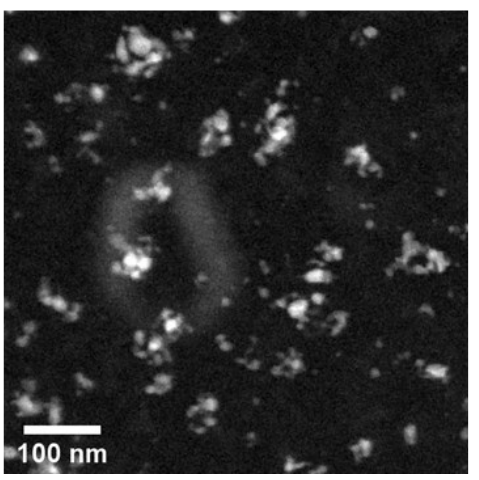

c) $\mathrm{H}_{2}-250^{\circ} \mathrm{C}, 12 \mathrm{~min}$

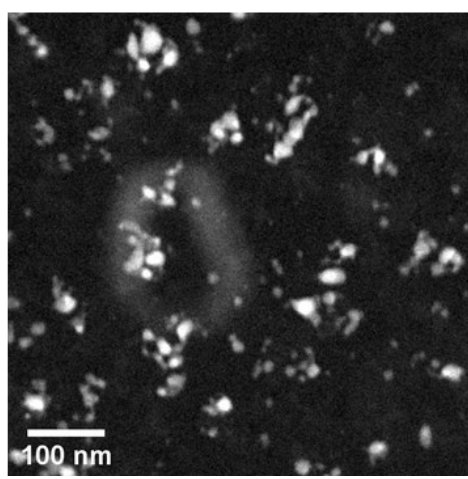

Figure S15: Reduction of Copper oxide nanoparticles at $250^{\circ} \mathrm{C}$, a) copper oxide NPs under oxygen after $20 \mathrm{~min}$ and under $\mathrm{H}_{2}$ after 4 and 12 min of flow, respectively in b) and c). Sample: Sputt - 2

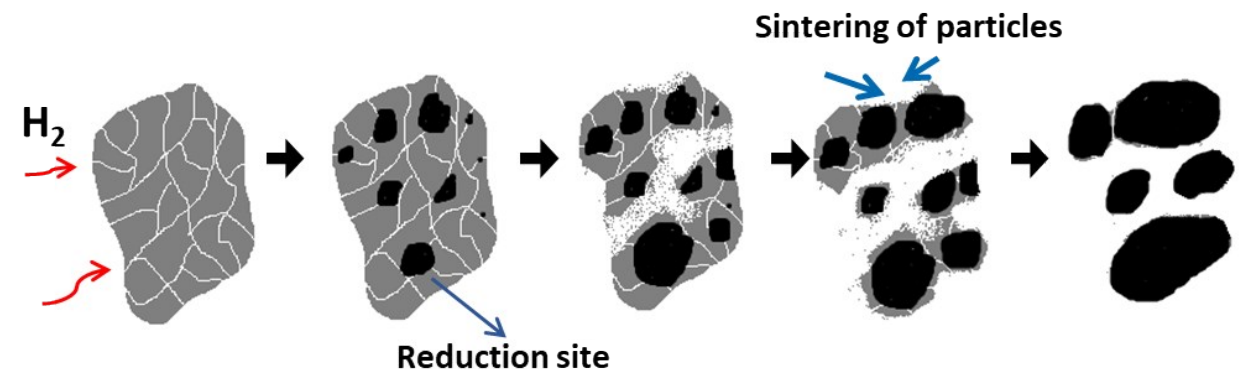

Figure S16: Schematic representation of Figure S15 illustrating the reduction of compact copper oxide nanoparticle which leads to the fragmentation into multiple nanoparticles of metallic copper. 


\subsection{Evaporation of the copper phase}
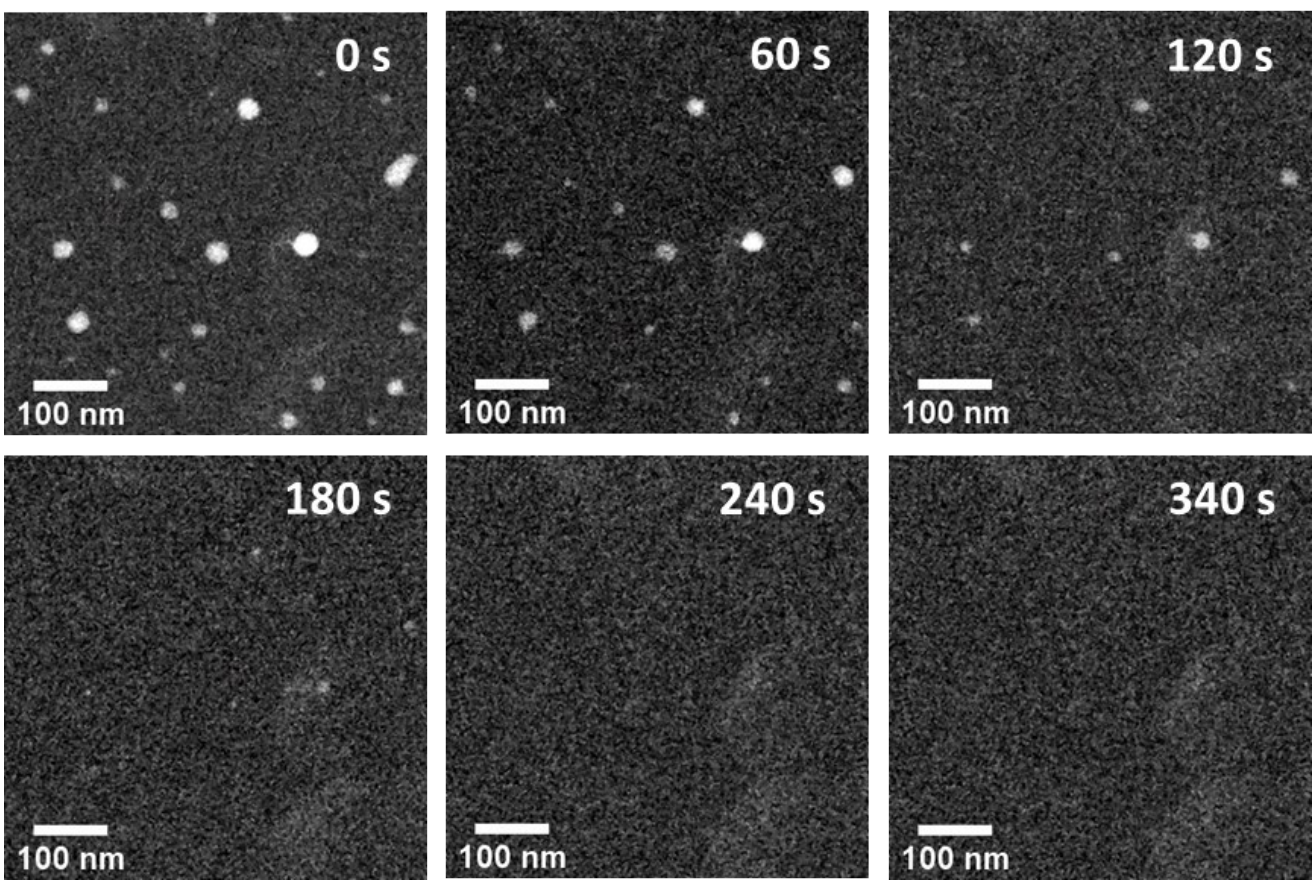

Figure S17: Evaporation of metallic copper NPs at $900{ }^{\circ} \mathrm{C}$ under $\mathrm{H}_{2}$ 


\section{References}

1 C.W. Bale, P. Chartrand, S.A. Decterov, G. Eriksson, K. Hack, R. Ben Mahfoud, J. Melançon, A.D. Pelton and S. Petersen, FactSage thermochemical software and databases, CALPHAD Journal, 2002, 62, 189-228.

2 J. Svoboda, F.D. Fischer and D. Vollath, Acta Materialia, 2009, 57, 1912-1919.

3 N. L. Peterson and C. L. Wiley, Journal of Physical Chemistry Solids, 1984, 45, 281-294.

4 R. Haugsrudz and T. Norby, Journal of Electrochemical Society, 1999, 146, 999-1004.

5 K. P. Rice, A. S. Paterson and M.P Stoykovich, Particle \& Particle Systems Characterization, 2015, 32, 373-380. 